\title{
MEMORIALIZATION AS THE ART OF MEMORY: A METHOD TO ANALYSE MEMORIALS
}

\author{
Ahenk YILMAZ
}

Received: 11.12.2009; Final Text: 07.05.2010

Keywords: memory; collective remembering; memorial; memorialisation; the Art of Memory (Ars Memoriae).

1. I originally developed this approach as part of my doctoral dissertation titled "Architectural Memorialization of War: Ars Memoriae and the Landscape of Gallipoli Battles" (Yilmaz, 2008) supervised by Assist. Prof. Dr. Şebnem Yücel Young.

2. For the reason that the art has undergone changes countless times all through the ages, the method has been called various names such as the method of loci, the art of memory, architectural mnemonic, mnemotechniques, and ars memoriae. Frances A. Yates, a specialist on the art of memory, claims that "the word 'mnemotechniques', though not actually wrong as a description of the classical art of memory, makes this very mysterious subject seem simpler than it is" (Yates, 1966, 4). For further details on the debate of the name of the art see: (Carruthers, 1990, 71). I prefer to use the expression of "the art of memory" in this study, for the reason that beyond being just a technique, it has been attributed philosophical, cultural, sociological effects on western traditions for centuries.

\section{INTRODUCTION}

Memorialization as the reification of past experiences crystallizes the bi-directional relation between memory and architecture in its pure form. Memorials, because of this long-established relation, constitute an expense area of knowledge where the theories of diverse -such as social, psychological, cognitive, urban or architectural- studies intersect. Addressing that interdisciplinary area, this study proposes a new approach derived from classical memorising technique of the art of memory (ars memoriae) to analyse different examples of architectural memorialization (1).

Beyond being just a technique, the art of memory has been considered as a form of art in the western tradition for centuries (2). As an essential part of rhetoric it was developed in the Classical period as a practical instrument by orators to perfectly memorize their speeches. In spite of the Renaissance elaboration of this art, its initial principles were very simple: putting the imagines (images), which were mental representations of memorised things, in well-ordered and mentally completely constructed loci (places), which could either be a part of a known building or an imaginary designed spatial organisation. Going out on a mental journey through these places provided the rhetoricians to memorise and remember their speeches. Furthermore, throughout the ages, this art has been embellished by diverse individuals not only who aimed at inscribing specific things to their personal memory, but also who wanted to affect the interpersonal memory of groups of individuals in order to generate particular modes of collective remembering (3). In comparison, the historical background mnemotechniques of modern times seems just a simplified form of this classical art par excellence.

In this study, I claim that if one looks at a memorial as the representational image of a specific event in a well-defined place built to remind the observers of that event, and then one can see the act of architectural 
3. During the Renaissance, for example, memory theatres of wood were constructed to store and transfer some information on certain subjects (Yates, 1966, 129-59). As another source on the subject see Whitehead, 2009, 36-8. Similarly, according to architectural historian Diane Favro, in Roman period "visitors were forced to conceptualise the placement of urban features and themselves in a relational manner based upon the location of monuments or other notable urban features." She argued in her book The Urban Image of Augustan Rome that "for the Romans, the most enduring recollections resulted from the stimulation of as many senses as possible. Movement through a physical environment was one of the most powerful ways to learn and to remember" (Favro, 1996, 5-6). As another source on the subject see "Displaying the Res Gestae of Augustus" (Güven, 1998). On the other hand, Napoleon III (1808-1873) conceived an architectural promenade, "a memory walk," for Paris based on the principles of the art of memory in order to define how the visitor should perceive and experience his city (Boyer, 1994, 14).

4. The first autonomous written material found on this art was dated roughly to the first century BC. There must have been various works on the art of memory before, because the first book on it, Ad Herennium dated roughly $90 \mathrm{BC}$ was in fact just a compiled textbook collected by an unknown rhetoric teacher for his students (Cicero, 1954). Hence, in the middle ages, this book had been mistakenly dedicated to well-

known Roman rhetorician Marcus Tulius Cicero and that mistake had continued to be made until the sixteenth century. Marcus Fabius Quintilianus' Institutio Oratoria_(2002) and Cicero's De Oratore (1942) had been other important Latin sources especially for the scholars of the Renaissance period after $A d$ Herennium.

5. There are numerous studies that focus on the importance of memory and memorialization in ancient cultures. The historian Patrick H. Hutton $(1993,27)$ describes the reasons behind today's understanding of the art of memory as an "arcane intellectual interest" in his book History as an Art of Memory. He claims "if it is a useful skill, it is not an essential one in a civilisation whose collective memory is stored securely in the printed word." Today's archive for reliable reference is the library or the computer, not the depths of a well-ordered mind." In their essay "Social Memory Studies: From 'Collective Memory' to the Historical Sociology of Mnemonic Practices" sociologists Jeffrey K. Olick and Joyce Robbins (Olick and Robbins, 1998) indicate the greater significance that the art had in earlier centuries than the modern world. The historian Le Goff explains the revolutionary effects of the proliferation of using letters in the western culture by means of a story. According to his story, in about 1174, the Count of Nevers declared to the inhabitants of Tonnerre that "the use of letters was discovered and invented for the preservation of the memory of things. What we wish to retain and learn by heart, we cause to be written down...so that what we cannot keep perpetually in our weak and fragile memories may be preserved memorialization as the materialisation of the basic principles of the art of memory. From this conceptual framework, mental representation becomes the physical form of the memorial and locus becomes the place where that form exists. This basic definition covers not only conventional commemorative structures, which are erected to preserve the memory of the past, but also existing buildings or natural formations, which are dedicated to remind the observer of a specific event or person. Considering that the art of memory provides a long lasting remembering about a chosen subject, this study argues that the analysing method derived from that art makes it possible to evaluate memorials in terms of the remembering they propose. The objective here is to remodel the modus operandi of the art of memory as a method to analyse the effectiveness of memorials in creating specific modes of remembering for their observers. Undeniably, the design strategy in an architectural memorialization depending on the principles of the art of memory enhances not only the particular mode of remembering during the occurrence of experience but also the permanence of that remembering on memory. The initial structure and principles of the art that was firstly defined in Ad Herennium -first autonomous survived work on the art- constitutes the theoretical basis of the method (4).

\section{MEMORY AS AN ART}

Frances Amelia Yates, the writer of the most comprehensive work on the art of memory, at the beginning of her book $(1966,4)$ points out the difficulty for us, moderns, to understand the importance of the art for ancient cultures. She claims that "we moderns have no memories at all ... but in the ancient world, devoid of printing, without paper for note-taking on which to type lectures, the trained memory was of vital importance." For pre-literate societies memorising techniques were particularly crucial, because the transmission of the assets of their cultures depended strictly on orality (5). Due to this vital importance, the story of its invention took a place in the Parian Chronicle i.e. the chronological table of ancient Greece. In this marble stele, the invention of the art of memory was attributed to well known Greek poet Simonides of Ceos (556-468 BC) (6).

The story of Simonides' remarkable invention is told in the book Lyra Graeca_(Edmonds, 1924, 307) (7). According to the story, one day the poet Simonides of Ceos was dining with Scopas who was a nobleman of Thessaly. Simonides started to sing a song in honour of Scopas but half of this poem consisted of a poetic ornament devoted to the twin gods, Castor and Pollux. The host, Scopas disliked the honour dedicated to the twin gods and stated that he was going to pay for just the half of the poem and Simonides was free to leave. Shortly afterwards, Simonides received a message that two young men were waiting to see him at the door of the hall. He went to see them but found no one waiting. Then suddenly, the dining-chamber collapsed on the host and all of his guests, and caused their death. After this catastrophic event the kinfolks of victims came to the hall, but unfortunately they were not able to identify the bodies to bury. At that point, Simonides noticed that he was able to help them to find the bodies owing to his recollection of the exact places of all guests just before the crash occurred. Due to this experience he invented the basic rules of the art of memory. In relation to this story, Cicero $(1942,467)$ expounds the basis of the art in De Oratore as follows:

"He [Simonides of Ceos] inferred that persons desiring to train this faculty must select localities and form mental images of the facts they wish to 
in writing and by means of letters that last forever" (Le Goff, 1992, 74-5). On the other hand, the French philosopher Paul Ricoeur $(2000,60)$ refers to an indispensable relation between paideia, education in ancient Greek and "exercises of memorization." The writer of Cultural Memory, Jan Assmann argues that ceremonies particularly in ancient cultures have two major functions; repetition and reanimation. In literate cultures writing and interpretive reading substituted repetition and reanimation (Assmann, 2001, 57)

6. For the texts of the Parian chronicle see Dictionary of Classical Antiquities: Mythology, Religion, Literature and Art (Seyffert, 1891).

7. The entire story is paraphrased from this passage unless otherwise stated. Marcus Tulius Cicero (106-43 BC) also tells the story of this invention in his book De Oratore (1942, 465-7)

8 . The relation between wax tablets and loci is also established in the first surviving work on the art of memory, Ad Herennium stating that "for the backgrounds are very much like wax tablets or papyrus, the images like the letters, the arrangement and disposition of the images like the script, and the delivery is like the reading" (Cicero, 1954, 209).

9. Coleman (1992) explains the importance and use of the art of memory in the Middle Ages in detail. The historian Savage-Smith (2003, 120-21) states that in Europe although "medieval commentaries of Ad Herennium, which dated from the twelfth century or so", were "usually silent on its mnemonic advice," in the contemporary Islamic societies the art of memory was glorified. She indicates the importance of the usage of the art in the maps claiming that Muslim maps drawn between the 4th and 10th centuries for especially trade and pilgrimage routes were supported with the principles of the art of memory in order to provide the viewer an easy recollection and remembrance.

10. In the Renaissance period, the art of memory started to be used not only for philosophical and scientific studies, but also for occultism (Rossi, 1983).

11. The basic principles of the art of memory are explained according to this passage unless otherwise stated.

12. Hutton $(1993,29)$ claims that the art of memory "as it was understood in its classical formulation provided not only a useful skill but also a way of understanding the world," for the reason that "the structure of [individual's] mnemonic system" was in accordance with their "conception of structure of knowledge and so implied a vision of the world." From this point of view, each distinct visualisation and its placement to different locus in the process of the art manifest the performer's interpretation of the subjects and events. remember and store those images in the localities, with the result that the arrangement of the localities will preserve the order of the facts, and the images of the facts will designate the facts themselves, and we shall employ the localities and images respectively as a wax writing tablet and the letters written on it" (8).

The unprecedented interests of Roman philosophers like Cicero in the art of memory makes it clear that in spite of the prevalence of literacy in Roman culture, the art kept its importance in this period as a practical instrument in Rhetoric. However, that importance gradually faded in social life during the long Middle Ages (9). At the dawn of the Renaissance the art had regained its popularity (10). Nevertheless, the availability of printed materials and the advancement of printing methods in the eighteenth century caused the art of memory to be erased from daily life day by day. Eventually, it became just one of the mnemotechniques for specific users to improve their personal memory.

\section{THE STRUCTURE OF THE ART OF MEMORY}

The initial description of the principles and the organization of the art of memory can be found in the first autonomous work on the art, $A d$ Herennium. The unknown writer in his book starts to explain the art of memory with the following statement: "Now let me turn to the treasurehouse of the ideas supplied by Invention, to the guardian of all the parts of rhetoric, the Memory" (Cicero, 1954, 205-25) (11). This statement assigns memory not only as the most precious part of the ideas but also as the protector of all parts of Rhetoric. The writer defines the art of memory as the artificial memory that can be improved by training contrary to the natural one, which is initially possessed with birth. The mental process of the art of memory performed by an individual consists of two main parts: committing things to memory and delivering them by memory. The person who wants to memorize something should create the mental representations for that thing and then should locate them in imaginary loci in a strictly defined order. When it becomes necessary, s/he should set out on a mental journey through those places and remember those things by means of the mental representations (12). The whole process makes things "to adhere longest in the memory," which "strengthened by a kind of training and the system of discipline" (Cicero, 1954, 207,221). The unknown writer describes the basic principles of the art as follows:
"The artificial memory includes backgrounds and images [locis et imaginibus]. By backgrounds I mean such scenes as are naturally or artificially set off on a small scale, complete and conspicuous, so that we can grasp and embrace them easily by the natural memory -for example, a house, an intercolumnar space, a recess, an arch, or the like. An image is, as it were, a figure, mark, or portrait of the object we wish to remember; for example, if we wish to recall a horse, a lion, or an eagle, we must place its image in a definite background."

The translated word "background" refers to the "locus," i.e. place in the original text. According to the writer of Ad Herennium there can be two kinds of loci; real and fictitious. The former consists of the places, which were lived in or physically visited beforehand by the orator such as the rooms of a house, buildings of a city, or sites of a journey. The latter is designed by the orator himself if there are not enough real places. The unknown writer recommends conceiving locus in solitude, because confusion weakens "the impress of the images." He does not advise the orators to envisage the locus neither too large causing "render the image 
13. In Ad Herennium the visualisation of an entire matter by means of a single image is exemplified as follows: "For example, the prosecutor has said that the defendant killed a man by poison, has charged that the motive for the crime was an inheritance, and declared that there are many witnesses and accessories to this act. If in order to facilitate our defence we wish to remember this first point, we shall in our first background form an image of the whole matter. We shall picture the man in question as lying ill in bed, if we know this person. If we do not know him, we shall yet take some one to be our invalid, but not a man of the lowest class, so that he may come to mind at once. And we shall place the defendant at the bedside, holding in his right hand a cup, and in his left tablets, and on the fourth finger a ram's testicles. In this way we can record the man who was poisoned, the inheritance, and the witness." The translator of Ad Herennium, Harry Caplan states that "the anatomists spoke of a nerve which extends from the heart to the fourth finger of the left hand where it interlaces into the other nerves of that finger" (Cicero, 1954, 214) Besides, he indicates that the Latin word testiculi means testicles and reminds the word testes in Latin, which means in English witnesses.

14. According to the writer, things which are not ordinary or banal, are much more suitable for recollection. He explains the images, which are "suitable for awakening recollection" as follows: "Now nature herself teaches us what we should do. When we see in everyday life things that are petty, ordinary, and banal, we generally fail to remember them, because the mind is not being stirred by anything novel or marvellous. But if we see or hear something exceptionally base, dishonourable, extraordinary, great, unbelievable, or laughable, that we are likely to remember a long time" (Cicero, 1954, 219). vague," nor too small that is "incapable of receiving an arrangement of images." Besides, according to the writer, the locus "ought to be neither too bright nor too dim, so that the shadows may not obscure the images nor the lustre make them glitter." It is required to conceive different locus for each different image in a series "so that we may never by confusion in their order be prevented from following the images." Rhetorician Marcus Fabius Quintilianus (ca. 35-100) in his book on rhetoric Institutio Oratoria $(2002,223)$ expounds the process of the art, which should be followed by the orator as follows:

The first thought is placed, as it were, in the forecourt; the second, let us say, in the living-room; the remainder are placed in due order all around the impluvium [the light-well in the centre of the atrium] and entrusted not merely to bedrooms and parlours, but even to the care of statues and the like.

In this process, the visiting sequence, in other words, the mental movement of the orator among numerous different images becomes crucial. In the art of memory, image refers to the mental representation of a word or a subject matter. The unknown writer of Ad Herennium elucidates how the mental representations should be as follows: "images must resemble objects, we ought ourselves to choose from all objects likeness for our use... Likeness of matter is formed when we enlist images that present a general view of the matter with which we are dealing." He also adds "often we encompass the record of an entire matter by one notation, a single image" (13). In addition, the writer warns the orators "some images are strong and sharp and suitable for awakening recollection, and others so weak and feeble as hardly to succeed in stimulating memory" (14). The unknown writer states "the things we easily remember when they are real we likewise remember without difficulty when they are figments, if they have been carefully delineated." Thus, if the orator wants to create an easily memorable image it should be well-delineated as a representation.

\section{THE ART OF MEMORY IN ARCHITECTURE}

In the art of memory, the whole structure of the mental process performed by an individual is based on architectural experience. That is why a contemporary historian of literature Mary Carruthers (1990, 71) defines the art of memory as the "architectural mnemonic." According to her, it is much more accurate to call it in association with architecture because of the spatial background which "the scheme of the artificial memory has." Thus, unsurprisingly, the architectural characteristics of each locus described in different sources of diverse periods had been followed dominant architectural intentions of that period. For instance, the locus was illustrated as a Roman house in Latin Rome, as a mental cathedral in the Middle Ages. Moreover, in the Renaissance period physical theatres started to be built according to the basic principles of the art of memory to create collective memorizing and remembering on the groups of individuals. The first memory theatre, designed by Giulio Camillo, was a wooden structure wide enough for at least two people to stand at the same time (Yates, 1966, 129-59). The stage of the theatre was designed for the visitors to stand and watch the images placed on different niches of the seven steps. The rationale of constructing those theatres was to reach "universal knowledge" and to build the "encyclopaedia of knowledge" (Rossi, 1983, 61 ). Due to similar purposes, numerous memory theatres were designed in 
the following years. The art of memory was used in all to provide visitors with the memorization of particular subjects.

Nevertheless, memorization has not been the only issue in the use of the art of memory in architectural context for centuries. It has been largely used to enhance the remembering of groups of individuals throughout the western history. Cultural historian Peter Burke $(1989,101)$ for instance indicates the resemblance between mental images of the art and physical representations of memorials. According to Burke, "practitioners of the so-called 'art of memory,' from classical antiquity to the Renaissance, emphasized the value of associating whatever one wanted to remember with striking images." He claims that "these were immaterial, indeed 'imaginary images': but material images have long been constructed in order to assist the retention and transmission of memories -'memorials' such as tombstones, statues, and medals, and 'souvenirs' of various kind." From this conceptual framework, a wide range of representations of the past in architectural memorialization can be considered as the physical form of the images of the art of memory. Similarly, Christine Boyer (1994) in her book The City of Collective Memory defines monuments and memorials as real mnemonic devices, which are erected "to stir one's memory." She also points out different usages of the art of memory in urban design and architectural practice. For instance, Boyer claims that the spatial organisation of the museums originates in the basic principles of the art of memory. She (1994, 133) states her argument as follows:
"The museum offers the viewer a particular spatialization of knowledge -a storage device-that stems from the ancient art of memory. Since classical times, as Frances Yates explained, the art of memory depended on developing a mental construction that formed a series of places or "topoi" in which a set of images were stored: images that made striking impressions on the mind.... By the nineteenth century, the museum had become such a memory device: its rooms or "topoi" were places to stop and to look around, to visually observe the common and contrasting features, the arbitrary analogical relationships that arranged the history of art into self-enclosed periods, schools, and styles" (15).

The spatial organisation and display of artefacts in art museums especially lead to thinking about the basic structure of the art of memory. Considering the role of remembering in relation to the function of a museum, such kind of an interaction does not seem a remote possibility. In her book, Boyer also gives an example of another kind of interaction between the art of memory and architectural practice with "the memory walk" proposed for the city of Paris. This was an architectural promenade conceived by Napoleon III for Paris based on the principles of the art of memory. She claims that the purpose of the project was "not only to bind his [Napoleon III] city of Paris into one cohesive unit," but also "to act as a memory walk through the historic monuments and grandiose architectural facades that represent the heroic accomplishments and communal responsibilities of his directorship" (Boyer, 1994, 14). In this sense, the city was transformed into a series of image-locus combinations. According to Boyer, such kinds of interventions, which depend on "controlling the behaviour of individuals", show that

15. It is possible to find numerous references to this relation in different works. David Carrier $(2003,64)$, for instance, argues that "... there is an important conceptual relationship between these techniques [the art of memory] and the complex narrative orderings provided by our art museums," for the reason that "a museum aims to provide a lucid plan, making its presentations of art clear in our memory." "architecture itself could affect and reform social behaviour." In those examples, the art of memory itself becomes an instrument in the process of reforming social behaviour by means of creating a particular mode of remembering.

Although the mental process of the art of memory consists of two main parts as "committing to the memory" and "delivering by memory" 
performed by only one person, all these urban and architectural examples refer to a division in this process. In this kind of example, two different individuals perform each one of the two parts of the process. Imagelocus combination is designed by a person who aims at affecting the remembering of groups of individuals concerning a particular subject. Thus, the observer just passively experiences the combination.

\section{REMODELLING THE ART AS A METHOD}

Through the medium of either a journey in the mind along the imagelocus combinations or the physical experience in a memorial, remembering is eventually a mental process. Thus, a method like the art of memory that provides effective, incisive and enduring remembering would be operative on not only mental organisations but also physical constructions of memory. From this conceptual framework, it is possible to claim that architectural memorialization as a representational image placed in a physically defined locus can be analysed by means of a method derived from the classical memorizing technique of the art of memory. Considering the efficiency of the usage of the art of memory in architectural practice on establishing a pre-defined way of remembrance, such kind of an analysis reveals the effectiveness of recollection proposed by an architectural memorialization in creating a particular mode of remembering.

The method that I propose in this study comprises three key components: image, locus and the relation between them. With respect to the logic of this method, any form of architectural memorialization either a grandiose monument or a modest landscape installation can be decomposed into these three components. "Image" corresponds to the physical representation of the commemorated past in a memorialization. It does not have to be a predetermined designed image. On the contrary, it can even be a particular remain determined to remind the observer of a specific event. The second one, "locus" is the place or the background of this representation in physical reality. Unlike mental places of the art of memory, the locus of this method constitutes a physical environment in which mostly the observer situates. The third one, "image-locus relation" refers to the physical interaction between the representation and its place. Despite the fact that the relation between the image and locus does not take place as a distinct element in the original mental process of the art of memory, it is handled as a separate component in this method for the reason that according to the logic of the art the image becomes memorable owing to the relevance with its place. The process of the method consists of the examination of these three components in a memorialization and the interpretation of the results of the examination according to the rules of the art of memory. The attributes of the components directly depend on the basic principles of the art of memory initially defined in Ad Herennium.

\section{IMAGE}

In terms of the principles of the art of memory, "image" is the mental representation of a word or a subject-matter. According to the method of this study, any part of a memorialization, which is built or dedicated to illustrate the historical event, can be considered as the representation of that subject-matter, thus its image. "Image" as the first component of the method consists of three main steps in the analysing process. The first step is the determination of the image. The second one is to draw a conceptual 
16. Italo Calvino (Calvino, 1972) in a part of his famous book La Città Invisibili [nvisible Cities] mentions the significance of the remains of the events in the collective remembering of groups of people. In his book, he "tries" to describe the city of Zaira, but according to him such kind of an endeavour is in vain, because of the intimate relation between the acts of understanding a place and knowing its history. According to him, for instance, an ordinary street-light gains a meaning when you know that once a despot was hanged on its post. and historical framework of this image. Finally, the last step is to examine the relation between the historical event and its representation, i.e. its image.

Determination of the image means defining the object, which is built or indicated to represent the historical event in a memorialization. In most of the traditional forms of monuments and memorials the image can easily be identified as the dominant object that rises in the urban pattern or on the landscape like an obelisk or an equestrian statue. However, in most of the counter-memorials and in the real landscapes of memory like battlefields or concentration camps it becomes hard to distinguish the image from the locus itself. That is why this step constitutes the basis of the analysis of the image. For instance, a bunker along the seashore of Northern France, which was built to be a part of a defence line, becomes the image of the memorialization of the Normandy landing as its memorialization (16). The bunker itself constitutes the image of that memorialization on the locus of shoreline. The key point in this phase is to define particular part of a memorialization, which reminds the observer of the commemorated event, as the image.

The second step of the analysis of the image depends on the investigation of the defined image in order to reveal its connections in different contexts. Mapping the contextual terrain of image in the theory and history of related disciplines helps us to understand the representation and provides us with a conceptual framework. This contextual terrain varies from one to the next because of the distinct characteristics of different images. Naturally, a figurative sculpture has different connections with diverse subjects from a self-referential memorial such as a preserved remain of a battle in an urban pattern like the demolished church tower of the city of Berlin. In these self-referential memorials, the image can be unique or incomparable thus it would not be possible to trace the canonical origin of the representation. On the other hand, sometimes the memorial stays the same but the event, for which the image of the memorial was dedicated, can change in time, therefore meanings may be shifted. Egyptian obelisks can be good examples of this situation. Most of them, which were erected to commemorate the victories of pharaohs, were moved to European cities to remind the visitors of the conquests of Roman commanders. That is why; the contextualization does not mean to manifest the architectural background of the image. Rather, it refers to an attempt to understand the representation in its conceptual, historical and philosophical context.

The final step in the analysis of the image is to examine the relation between the event and its representation. The unknown writer of Ad Herennium recommends the orators to visualise well-delineated representations of the subject-matters, due to the fact that the one who tries to memorize and remember something should not hesitate about the exact meaning of the representational image. The directness of the relation between the subject-matter and its representation prevents the potential confusions. From this point of view, it is possible to claim that the more unequivocal that relation is, the more singular the remembering process of different individuals will become. In terms of architectural memorialization, to reify an event into an image diversifies into numerous forms. In most of the figurative monuments, the relation between the event and its representation reveals itself directly. For instance, if a person is commemorated in a memorial, the image is mostly formed from the representation of the physical entity of that person. This constitutes 
17. The simplicity of the monument strongly impressed the committee of the competition of the Vietnam Veterans Memorial organised in 1981, because the donors of the memorial did not want a monument with a strong political statement. However, after the competition a "noisy disputation broke out in the public," for the reason that the design was accused of not being celebratory and heroic. Eventually, the secretary of the department of Interior decided that the Wall should "be supplemented, if not supplanted, by a more heroic, representational, figural memorial." Thus, male and female soldiers figures were added in 1984 and 1993 (Hass, 1998, 14-20)

18. James Edward Young $(1998,101)$ argues that "abstract forms still offer artists the widest possible variety of expression" and "Maya Lin's succinctly abstract Vietnam Veterans Memorial, for example, commemorates the nation's ambivalence toward the Vietnam War and its veterans in ways altogether unavailable in figuration."

19. Similarly, in his essay "Language and Space" Stephen C. Levinson claims that "human beings think spatially," and mental spatial arrangements "can even give us maps of the mind, as exploited in the classical and medieval art of memory." According to Levinson, mental thinking always tries to form spatial arrangements for the new knowledge; ancient rhetoricians must have been noticed and taken advantages of it (Levinson, 1996, 357). an unequivocal relation. Nearly all monuments of heroic leaders have such kind of a direct relation. Moreover, memorialising an event with its remains may also constitute an unequivocal relation between that event and its representation. The image of a railway, which disappears in the darkness of the gate of the Auschwitz Concentration Camp, evokes the same event in the collective remembering process of most of the individuals.

On the other hand, some significant events are memorialised abstractly so that it becomes impossible to establish a relation with the representation and the event. Maya Lin's Vietnam Veterans Memorial can be a good example to this situation. It is a simple granite $\mathrm{V}$ shaped wall lodged and embedded into a hill (Hass, 1998). The surface of the wall was designed as a polished black granite for not only for the reason that the names of the victims could be inscribed on it but also so that the visitors could see themselves behind the reflected surface of the names (17). The monument provides the observer with nothing but the names; "a great void of meaning." It was constructed to instigate the visitor to contemplate on the Vietnam War but through diverse ways of different personal memories on that event. There is no direct denotation between the event and its representation. The holocaust historian and theorist James Edward Young in his essay "The Biography of a Memorial Icon," $(1989,101)$ claims that "in its hermetic and personal vision, abstraction encourages private visions in viewers, which would defeat the communal and collective aims of public memorials" (18). It is an undeniable fact that each remembering process of individuals has distinct characteristics. However, a direct denotation between the event and its representation minimizes the variations in the collective remembering process. When that relation weakens the diversity of connotations proposed by a memorial increases.

\section{LOCUS}

Locus is the second component of the analysing method of this study. Simonides' catastrophic experience onwards the role of the place in remembering has been the core of the classical memorizing technique of the art of memory. This experience manifested that memory does not only dwell in the mind, but also in place. In his seminal work Remembering: A Phenomenological Study, Edward S. Casey $(1987,186-87)$ claims that "place" can be considered as a "container of experiences that contributes so powerfully to its intrinsic memorability." According to him, "we might even say that memory is naturally place-oriented or at least placesupported" (19). In the analysing method of this study, "locus" is examined in three main steps as "determination," "detachment" and "guidance." "Determination" corresponds to the definition of the area and the boundaries of the particular locus of a memorialization. The second step, "detachment" requires to investigate the visible and invisible boundaries of the determined locus. The last one, "guidance" refers to the examination of the area of the locus in terms of the movements of individuals.

The "determination" phase of the analysis is similar to the first step of the examination of the image. In this step, the objective is to define the field and the boundaries of the locus of memorialization. The complexity of the implementation of this step varies from one memorialization to another for the reason that the boundaries of the locus of a memorial are not always explicitly identifiable. On one hand, the locus may seem to extend indefinitely. In such memorials, the peripheries of their loci 
should be determined in relation to their images. For instance, the locus of an obelisk, which solely stands on a landscape, is encircled by the area dominated by the image of the obelisk. On the other hand, the image may be embedded in a locus so that the image and locus become inseparable. The memorialization of a battle by means of its trenches in a vast battlefield can be a good example of this situation. In such a case, similar elements of the memorialization should be determined both as image and locus.

"Detachment," the second step of the analysis of locus, corresponds to the examination of the boundary of the locus in order to understand the relation between the inside and outside of the locus in terms of the perception of the individual. The unknown writer of Ad Herennium recommends the orators conceiving the locus as a quite, serene, closed and bounded architectural place in order to be able to provide the individual with concentration in contemplation. From the point of view of the art of memory, it is possible to claim that if the locus of a memorial detaches the visitors from the actual flow of time and space, the remembering becomes much more effective and long-lasting. The visible and invisible boundaries of a locus may detach the individual from the actual space. However, the utter detachment is mostly provided with introversion, thus enclosure (20). The locus which detaches the individual from the actual flow of time and space does not only provide the visitor with a suitable milieu for concentrated contemplation but also creates a different reality for the individual whereby a spatial experience and therefore a specific mode of remembering can be manipulated.

"Guidance" is the third and the final step of the examination of locus. In this step of the analysis, the locus is examined in relation with the movements of individuals. In terms of the basic principles and the rules of the art of memory, the (mental) movement of the orator constitutes a crucial part of the process of not only committing memory but also delivering by memory. The image-locus combinations should thus be conceived in a succession, and should be mentally visited in the correct order. Otherwise, the orator cannot accomplish to remember his speech fluently. Controlled and defined mental movements in those architectural spaces make particular modes of remembering possible (21). From this basis of the art of memory, it is possible to claim that the more the movement of an individual is guided in the locus of an architectural memorialization, the more effective that individual's processes of committing memory and delivering by memory will become. In the locus of a memorial, where the movements of individuals are defined by means of paths, boundaries and marks, even their viewpoints are determined

20. The French philosopher Gilles Deleuze (2004, 350-56) signifies the importance of the control of space and time in establishing domination on individuals particularly in the "environments of enclosure" in his essay "Postscript on the Societies of Control." In his seminal work Discipline and Punish on the relation between power and space Michel Foucault $(1975,135-69)$ also mentions the role of enclosure in controlled places.

21. As a matter of fact, every spatial organisation aims to define individuals' movements to a certain degree. They are designed to "ensure a certain allocation of people in space, a canalisation of their circulation, as well as the coding of their reciprocal relations" (Foucault, 1984, 253). In relation to the use or the function of the building, this mechanism can be vague or strictly defined. beforehand, a specific spatial experience is proposed, and thus a particular mode of remembering is created.

\section{IMAGE-LOCUS RELATION}

The "image-locus relation" constitutes the third component of the analysing method. In this autonomous phase, the examination focuses on the mutual relation between the image and locus of an architectural memorialization. According to the classical memorizing technique of the art of memory, owing to the place the image becomes memorable. The localization of the representation constitutes the essence of accurate memorization and remembrance. Nevertheless, to establish a constant relation between the image and locus is not functional for the mental palaces of the art of memory, due to the requirement of using the 
same arrangements of loci for diverse representations in different times, like writings on wax tablets. However, in terms of architectural memorialization a constant relation is inevitable, due to the fact that the loci of memorials are fixed places.

It is an undeniable fact that the perception of a place through five senses enhances the remembering process of an individual (Baddeley, 2002). Dolores Hayden claims, "the encoding of long-term memory connected to places is particularly strong" $(2000,144)$. Therefore, if the image of a memorialization proposes spatial experience to the visitor, many more senses are affected by the experience, thus an effective remembering occurs. Similarly, if the locus turns into the image of a memorialization, the relation between the image and locus gets strong, so does the particular mode of remembering. If there is no relation between the image of a memorialization and its locus, the representation of the significant event becomes de-contextualized or even nomad, thus remembering weakens. In this phase of the analysis, the examination centres on a question of how much the image proposes spatial experience, or the locus is objectified. In a memorial, the image may have spatial characteristics, or sometimes the locus itself turns into an object. Most of the Holocaust memorials, which have been built especially since the collapse of the Wall, have images that propose spatial experience like Peter Eisenman's National Holocaust Memorial or Karin Daan's Homomonument. On the other hand, in some examples like Auschwitz Concentration Camp or Anzac Commemorative Site in Gallipoli, the real place of the memory, in other words the locus is objectified. From this point of view, it is possible to claim that the more the relation between the image and locus is established, the more effective remembering will become.

\section{CONCLUSION}

In the milieu of pluralistic intentions of art and architecture of the twentyfirst century, memorials are erected not merely to become a promise of enduring remembering, but also the symbols of ephemeral memory. Therefore, memorialization varies from building up grandiose structures to spontaneous, temporary acts of commemoration. Moreover, considering the complexity of conceptual background that nourishes memorialization, which is mapped by different cultural, social and political dynamics, it becomes difficult to comprehend diverse examples of memorials via a single conceptual framework. This lack of common ground prevents researchers from making comparative analyses among memorials, which are built in different styles, periods or geographies. The method of analysis, developed in this study thereby depending on the basic structure of a foremost classical memorizing technique of the art of memory aims at fulfilling this lack.

The method developed in this study depending on the classical memorizing technique of the art of memory consists of three main components as image, locus and image-locus relation. According to the logic of this method, it is possible to decompose any form of commemorative structure by the use of these components. Such decomposition enables researches to categorize diverse examples of memorials and to reveal their similarities and differences within a collective framework. Therefore, by means of this method, it becomes possible to make a comparative analysis among not only traditional and conventional memorials like obelisks or triumphal arches but also 
the real environments of memory like fields where bloody battles were held or places where a national hero was assassinated. To be able to classify distinct memorials according to their basic components answers particularly the purposes of the studies on different memorialization attempts of a specific event in different time periods or geographies.

Furthermore, with the help of the method of analysis, this study it becomes possible to examine the peculiarities of the mode of remembering proposed by a memorialization. Each memorialization act suggests for the observer to commemorate a significant historical event. Some of them function just as a reminder to recall the event on the mind of the observer, but some define a specific mode of remembering. The method developed in this study provides to demonstrate prominent peculiarities of the works of architectural memorialization in imposing specific forms of remembering upon the observer. According to the method, if a memorial is composed of an image, which has a direct denotative relation between the commemorated historical event in that memorial; a locus, which is detached from surroundings and has a clearly defined path of visiting experience; and an image-locus relation, which cannot be separately perceived; possibilities of different modes of remembering proposed by that memorial decreases. In other words, the more the three components of a memorial -image, locus, and image-locus relation- fulfil the requirements defined initially in the classical memorizing technique of the art of memory, the more that memorial will conduct individuals through a specific mode of remembering.

\section{REFERENCES}

ASSMANN, J. (2001) Kültürel Bellek: Eski Yüksek Kültürlerde Yazı, Hatırlama ve Politik Kimlik, tr. by A. Tekin, Ayrıntı, İstanbul.

BADDELEY, A. D. (1997) Human Memory: Theory and Practice, Psychological Press, London.

BOYER, C. (1994) The City of Collective Memory: Its Historical Imagery and Architectural Entertainments, MIT Press, London, Cambridge, Mass.

BURKE, P. (1989) History as Social Memory, Memory: History, Culture, and the Mind ${ }_{\llcorner}$ed. T. Butler, Basil Blackwell, Oxford, New York.

CALVINO, I. (2002) Görünmez Kentler, tr. by I. Saatçığlu, Remzi, İstanbul.

CARRIER, D. (2003) Remembering the Past: Art Museums as Memory Theatres, Journal of Aesthetics and Art Criticism (61) 61-5.

CARRUTHERS, M. J. (1990) The Book of Memory: A Study of Memory in Medieval Culture, Cambridge University Press, Cambridge.

CASEY, E. S. (1987) Remembering: A Phenomenological Study, Indiana University Press, Bloomington, Ind.

CICERO, M. T. (1942) De Oratore, tr. by E.W. Sutton and H. Rackham Harvard University Press, Cambridge, Mass.

CICERO, M. T. (1954) Rhetorica Ad Herennium: De Ratione Dicendi, trans. H, Caplan, ed. G. P. Goold Harvard University Press, Cambridge, Mass.

COLEMAN, J. (1992) Ancient and Medieval Memories: Studies in the Reconstruction of the Past ${ }_{L}$ Cambridge University Press, Cambridge, UK. 
DELEUZE, G. (1997) Postscript on the Societies of Control, Rethinking Architecture: A Reader in Cultural Theory, ed. N. Leach, Routledge, London, New York; 309-12.

EDMONDS, J. M. (1924) Lyra Graeca 2, Harvard University Press Cambridge, Mass.

FAVRO, D. (1996) The Urban Image of Augustan Rome, Cambridge University Press, Cambridge, New York.

FOUCAULT, M. (1979) Discipline and Punish: The Birth of the Prison ${ }_{L}$ tr. by A. Sheridan, Vintage Books, New York.

FOUCAULT, M. (1984) Space, Knowledge and Power, The Foucault Reader, ed. by P. Rabinow, Pantheon Books, New York, 239-56.

GÜVEN, S. (1998) Displaying the Res Gestae of Augustus: A monumental Image for All, Journal of the Society of Architectural Historians (57:1) $30-45$.

HAYDEN, D. (2000) Landscapes of Loss and Remembrance: The case of Little Tokyo in Los Angeles, War and Remembrance in the Twentieth Century, ed. by J. Winter and E. Sivan, Cambridge University Press, Cambridge, UK.

HASS, K. A. (1998) Carried to the Wall: American Memory and the Vietnam

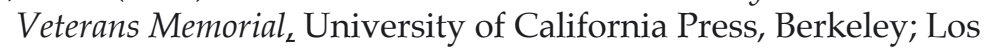
Angeles; London.

HUTTON, P. H. (1993) History as the Art of Memory, University Press of New England, Hanover.

LE GOFF, J. (1992) History and Memory, trans. S. Rendall and E. Claman, Colombia University Press, New York.

LEVINSON, S. C. (1996) Language and Space, Annual Review of Anthropology (25) 353-382.

OLICK, J. K. and Robbins, J. (1998) Social Memory Studies: From 'Collective Memory' to the Historical Sociology of Mnemonic Practices, Annual Review of Sociology (24) 105-140.

QUINTILIANUS, M. F. (2002) Institutio Oratoria, trans. and ed. D. A. Russel, Harvard University Press, Cambridge, Mass.

RICOEUR, P. (2004) Memory, History, Forgetting ${ }_{2}$ tr. by K. Blamey and D. Pellauer, University of Chicago Press, Chicago.

ROSSI, P. (2006) The Liber ad Memoriam Confirmandam of Roman Lull, Logic and the Art of Memory: The Quest for a Universal Language, trans. S. Clucas, Continuum, London; New York.

SAVAGE-SMITH, E. (2003) Memory and Maps, Culture and Memory in Medieval Islam: Essays in Honour of Wilferd Madelung ${ }_{\alpha}$ ed. F. Daftary and J. W. Meri, I. B. Tauris, London; New York; 109-27.

SEYFFERT, O. (1891) Dictionary of Classical Antiquities: Mythology, Religion, Literature and Art, eds. H. Nettleship and J. E. Sandys, William Glaisher London.

WHITEHEAD, A. (2009) Memory, Routledge, New York.

YATES, A. F. (1966) The Art of Memory, University of Chicago Press, Chicago, London. 
Alındı: 11.12.2009; Son Metin: 07.05.2010

Anahtar Sözcükler: bellek; kolektif hatırlama; ant; antlaştırma; Bellek Sanatı (Ars Memoriae)
YILMAZ, A. (2008) Architectural Memorialization of War: Ars Memoriae and the Landscape of Gallipoli Battles, Unpublished PhD Thesis, İzmir Institute of Technology, Faculty of Architecture, İzmir.

YOUNG, J. E. (1989) The Biography of a Memorial Icon: Nathan Rapoport's Warsaw Ghetto Monument, Representations (26) 69-107.

\section{BELLEK SANATI OLARAK ANITLAŞTIRMA: ANITLARI ANALIZ ETMEK İÇIN BİR YÖNTEM}

Günümüz çoğulcu sanat ve mimarlık akımları içerisinde, bir olayı ya da bir kişiyi anıtlaştırmak ezici, hükmedici yapılar dikmekten, günlük ve geçici anma mekanları oluşturmaya kadar uzanan büyük bir çeşitlilik göstermektedir. Bu çeşitlilik, bellek ve onun anıtlaştırılması kavramlarının kültürel, coğrafi, felsefi yada dönemsel algılanış farkları ile de birleşince, gerek mimari dil gerek de anma yaklaşımı olarak birbirinden tümüyle farklılaşan anı örneklerini aynı çerçeve içerisinde anlamaya çalışmak ve karşılaştırmak neredeyse olanaksız hale gelmektedir. Bu çalışma ise dayandığı klasik ezberleme tekniği olan 'Bellek Sanatı'nı (Ars Memoriae) temel alarak tüm bu farklı anıtlaştırma biçimlerini araştırmamızı ve karşılaştırarak anlamamızı sağlayacak bir analiz yöntemi önerir.

Belagat sanatını icra edenlerin antik çağlardan beri kullanageldikleri bellek sanatı, en saf haliyle ezberlenmek istenen yazı ya da konunun hayali olarak yaratılan görsel imgelerinin zihinde oluşturulan mekanlar silsilesine sırayla yerleştirilmesi ve ezberlenmiş halinin gerektiğinde bu mekanların zihinsel olarak ziyaret edilerek imgeler aracılığı ile eksiksiz bir şekilde hatırlanması olarak tarif edilir. Güncel hayattaki önemi azalmış olsa da günümüze kadar etkinliğini korumuş olan bu teknik, çağlar boyunca sadece zihinsel olarak kişilerin kendi hafızalarını güçlendirmeleri için değil, özellikle Rönesans döneminden itibaren fiziksel olarak da kolektif hatırlamayı biçimlendirmek amacıyla kullanılmıştır. İnşa edilmiş bellek tiyatroları, kentler için tasarlanmış olan bellek rotaları yada müze sergileme mekan izlekleri bellek sanatının hatırlamayı tekilleştirmek için kullanılmasına yönelik tarihsel örnekleri oluşturur.

Tüm bunların yanında, anıtlar hatırlatılmak istenen olay ya da kişinin görsel temsilinin belirli bir yerde inşa edilmesi olarak tanımlanırsa, mimari anitlaştırma bellek sanatı'nın temel prensiplerinin fiziksel dünyadaki en somut biçimi ve en fazla sayıda inşa edilmiş örneği haline gelir. Bu tanımı esas alarak yola çıkan bu çalışma, bellek sanatının prensiplerini farklı anıtlaştırma yaklaşımlarının analiz edilmesine olanak verecek bir yönteme dönüştürür. Yöntem, bellek sanatı'nın günümüze kadar kalabilmiş otonom ilk kaynağı olan Ad Herennium adlı metindeki en temel hali dayanak kabul edilerek biçimlendirilmiştir. Analiz yöntemi İmge, Yer ve İmge-Yer ilişkisi şeklindeki üç elemandan oluşur. Anıtları bu elemanlar aracılı̆̆ı ile analiz etmek araştırma yapan kişiye, bakılan örneklerin anıtlaştırma yaklaşımları ne denli farklı olursa olsun ortak bir çerçeve oluşturma ve ayrıca, önerdikleri hatırlamanın bireylerin hatırlama biçimini yönlendirme niteliğini değerlendirme olanağı verecektir. 
AHENK YILMAZ; B. Arch., M. Arch., Ph.D.

Received B.Arch (1998) Dokuz Eylül University, İzmir; M.Arch (2001) and Ph.D in Architecture (2008) from İzmir Institute of Technology. From 2008 on, she has been teaching as part-time instructor at Dokuz Eylül University and İzmir University of Economics. ahenkyilmaz@gmail.com 